\title{
He awa whiria-braided rivers: Understanding the outcomes from Family Start for Māori
}

\section{Fiona Cram, Min Vette, Moira Wilson, Rhema Vaithianathan, Tim Maloney, and Sarah Baird}

In Aotearoa New Zealand a braided rivers-he awa whiria metaphor is facilitating conversations between Māori (indigenous peoples) and non-Māori researchers about the integration of knowledge systems. This article explores how an approach based on he awa whiria can work in practice in the examination of the efficacy for Māori whānau (families) of the government's intensive home-visiting programme, Family Start. A retrospective impact evaluation of Family Start for children born from 2004 to 2011 examined the outcomes for children in families receiving Family Start, compared to a matched control group who did not receive this service. The awa-or knowledge streams - called upon to inform the consideration of the findings for Māori from this evaluation related to: Family Start and its child development and parenting curriculum Āhuru Mōwai and Born to Learn, whānau ora, and measures of whānau wellbeing, other indigenous home-visiting programmes, the impact evaluation method, and the indigenous data sovereignty movement. Braiding (whiria) across these knowledge streams offered new perspectives on the impact evaluation's results for Māori. These results suggested that 
Family Start reduced post-neonatal mortality for Māori children, regardless of whether the Family Start provider was Mãori or nonMāori. Māori children receiving Family Start were more likely to be fully up-to-date with immunisations at age 2 , and their mothers were more likely to access services for treatment of addiction relative to the control group. The impact of Family Start on child maltreatment was uncertain. He awa whiria provided a vehicle for Māori and non-Māori research and practice expertise to contribute knowledge to understanding Family Start and explaining these findings. This metaphor holds the promise of supporting Māori engagement with the growing use of linked administrative data.

In 1998 the Aotearoa New Zealand government introduced Family Start, an intensive home-visiting programme for pregnant mothers and families with preschool children. The programme targets families and whānau ${ }^{1}$ whose social, economic, and family circumstances put at risk good health, education, and social outcomes for their children. Referrals are made by a range of organisations and individuals, and families and whānau may self-refer. Families and whānau are generally enrolled prior to their child's first birthday and remain in the programme until the family can confidently cope and access support on their own, or the child reaches school age (Ministry of Social Development, 2016). Half the children served by Family Start are Māori (Vaithianathan, Wilson, Maloney \& Baird, 2016).

A recent impact evaluation of Family Start covered children entering the programme over the period 2004 to 2011-12 (Vaithianathan et al., 2016). During this time, Family Start workers made regular home visits (either weekly or fortnightly depending on need) and sought to improve parenting using a structured child development and parenting curriculum called "Āhuru Mōwai and Born to Learn" (see below). The present article describes how a group composed of 
Māori and non-Māori researchers (Cram and Wilson) and a former Family Start manager and current programme adviser (Vette) worked together to reflect on the impact evaluation's findings for whānau, and the study's contributions and limitations. We framed the shared journey within a metaphor of he awa whiria-braided rivers.

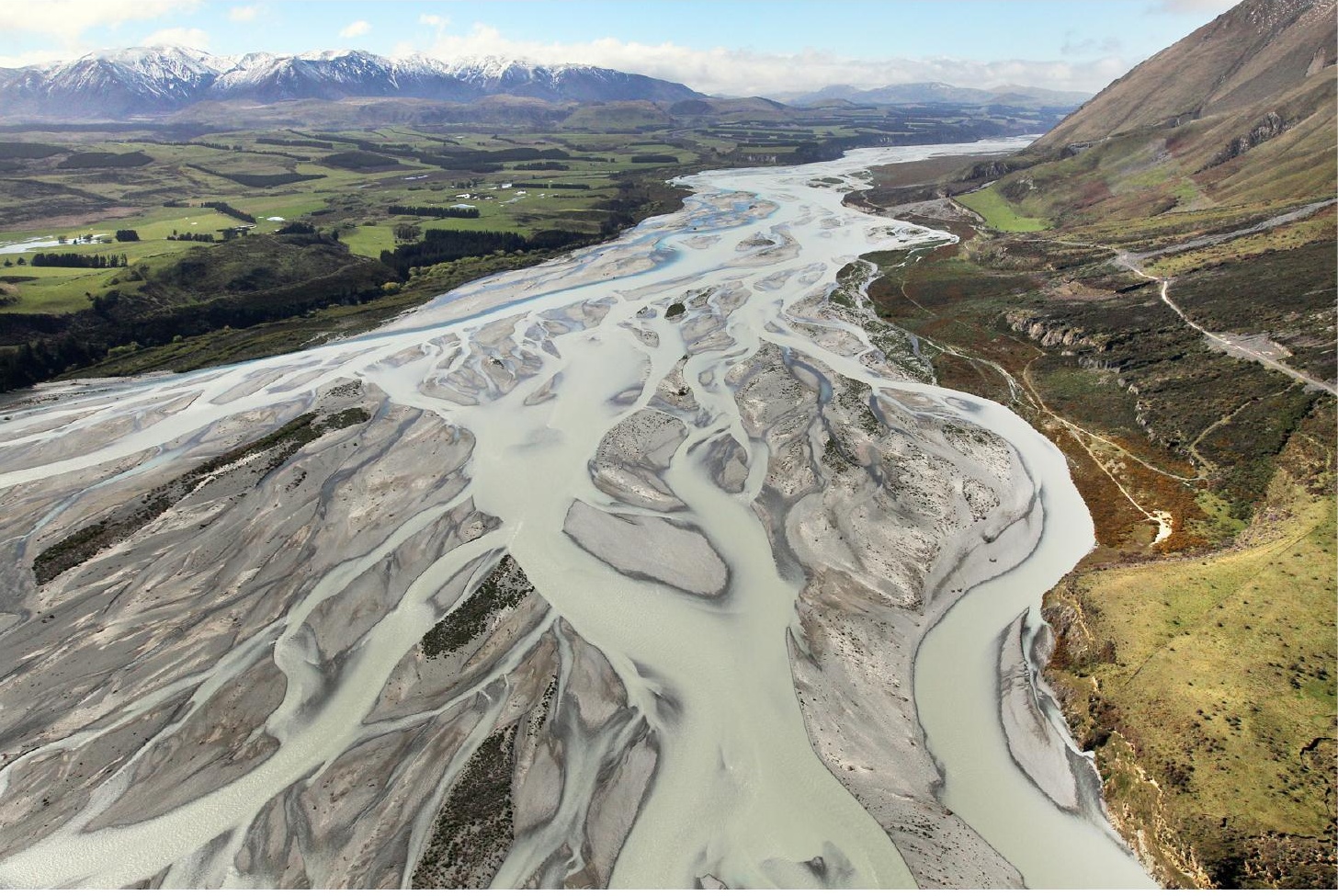

Figure 1. Rakaia River, Canterbury (Hargreaves, 2012)

(Credit. Stuff / The Press)

\section{He awa whiria-Braided rivers}

Braided rivers are geologically unusual as over all or part of their length they flow in a network of multiple channels separated by 
alluvial islands (see Figure 1). The metaphor of he awa whiria ${ }^{2}$ braided rivers has been promoted by Angus Macfarlane and others as a framework for drawing upon both Western science and mātauranga Māori (Advisory Group on Conduct Disorders, 2013; Hong, Arago-Kemp, Macfarlane, \& Poulton, 2015; Superu, 2018). The integration of knowledge that may occur when these knowledge systems mix and mingle is described in the metaphor as having the potential to "create new knowledge that can be used to advance understanding in two worlds" (A Better Start National Science Challenge, 2015, p. 16). "The metaphor also acknowledges the perpetual changes in our knowledge and understandings as the braided river is fed by new waters" (Berman, Edwards, Gavala, Robson, \& Ansell, 2015, p. 10).

The he awa whiria metaphor has been used by Māori and nonMāori researchers working together to examine children's learning journeys from childhood to school (Paki \& Peters, 2015), and to develop ngā mātāpono (health-promoting schools' values) (Cognition Education, 2015). The metaphor also occurs in international literature to describe collaborative, cross-disciplinary relationships (for example, Curtis, Reid, Kelley, Martindell and Craig (2013)). He awa whiria-braided rivers was adopted by Superu (Social Policy Evaluation and Research Unit) "in recognition of the Crown's unique relationship with the Màori Treaty partner as tangata whenua" (Hong et al., 2015, slide 3).

For our group, he awa whiria signals the braiding of Western and Māori knowledge systems. We conceived of the awa (river) flowing towards and into the sea, symbolic of a progression towards a multitude of opportunities and perspectives represented by the expanse of the ocean. Our he awa whiria journey included debates about the responsiveness of Family Start to Māori, and how the findings of the impact evaluation might be interpreted for Māori. The remainder of this article describes the various knowledge systems our group drew 
upon, and the new perspectives on the impact evaluation findings arrived at because of their braiding.

\section{He awa-The knowledge systems}

Six awa are described in this section. Overviews of Family Start, Āhuru Mōwai and Born to Learn, whānau ora, and indigenous home-visiting programmes provide a context for understanding the findings of the impact evaluation. Sections on the impact evaluation and on data sovereignty talk to the "how?" (i.e., method) and "what's missing?" from the linked administrative data used for the impact evaluation. In the following section, Whiria-The Braiding, the findings of the impact evaluation for Māori are presented, and we draw on the awa to provide explanations for these findings as well as to explore the contribution and limitations of the impact evaluation.

\section{Family Start-A brief history}

Family Start was developed in the late 1990 s as a response to concerns about intergenerational cycles of disadvantage, gaps in services at the local level, and poor co-ordination of services where they did exist (Irvine, 2003; Ministry of Health, 2002; Evaluation Management Group, 2003). ${ }^{3}$ Family Start was based on Early Start, a programme delivered in Christchurch NZ, that was in turn informed by the Hawaiian programme, Healthy Start (Fergusson, Boden, \& Horwood, 2012). An important feature that distinguished Family Start from the Christchurch Early Start programme was the strong emphasis on ensuring that provider organisations were culturally representative of their communities (Cribb, 2009). Funding and governance for the introduction of Family Start to three pilot sites in 1998 came from health, child welfare, and education agencies (Irvine, 2003), and Māori organisations were selected as Family Start providers in all pilot sites. 
Several changes were introduced into Family Start from its inception to 2004-the beginning of the period included in the impact evaluation. The programme was expanded in 1999 and 2000 to 16 sites. Beginning in 2003, changes were introduced in response to an evaluation that highlighted the need for trained staff, quality supervision and organisational accountability (Evaluation Management Group, 2003). The period from 2003 to 2005 saw measures intended to strengthen national governance and contracting arrangements, and improve needs-assessment tools. Then from 2005 to 2007 the programme was expanded once more, and Family Start workers were newly expected to have a formal tertiary qualification in social work, nursing, or early childhood education. Study awards were introduced to support workers to obtain these qualifications. ${ }^{4}$ By the end of 2007, Family Start was operating in 30 out of the country's 74 city and district council areas (Territorial Local Authorities or TLAs ${ }^{5}$ ).

A 2009 review confirmed that Family Start had many of the design features needed for an effective early intervention service, including cultural responsiveness, but highlighted variation in performance across providers. Improved contract management was pointed to as a means of addressing poor performance and exiting poorly performing providers (Cribb, 2009). This review, together with research aimed at identifying improvements that would increase effectiveness in preventing child maltreatment and promoting child development (Fielding, 2011), informed changes implemented in 2011 and 2012. These included revised referral criteria to more tightly target highneeds families, an increased focus on maltreatment prevention and child safety, introduction of practice advisers, and introduction of standardised contracts across all providers that set out key performance indicators and penalties for nonperformance (Martin, 2014). ${ }^{6}$ Although it continued to be expected that Family Start providers would deliver the service in a manner that was culturally responsive 
to their communities, the degree to which programme content and service delivery specifications were centrally determined increased from 2004 to $2011 .^{7}$

At the end of the period covered by the impact evaluation (i.e., 2011), Family Start was available in 30 TLAs and there were 44 TLAs where Family Start had never been offered (Box 1). Māori providers were involved in the delivery of the programme in all the initial Family Start sites (Ministry of Health, 2002), and half of the sites operating in 2011.

1998: Family Start pilot established in 3 TLAs: Rotorua, Waitakere, Whangarei.

1999-2000: Expansion to a further 13 TLAs: Dunedin, Far North, Gisborne, Hamilton, Hastings, Horowhenua, Invercargill, Kawerau, Masterton, Nelson, Porirua, Wanganui, Whakatane.

2005-2007: Enhancement and further expansion:

Q2 2005: 2 TLAs phase in: Auckland and Opotiki Q1 2006: 2 TLAs phase in: Lower Hutt, Manukau Q3 2006: 4 TLAs phase in: Napier, Taupo, Waikato, Papakura Q4 2006: 4 TLAs phase in: Buller, Grey, Hauraki, Wairoa Q3 2007: 2 TLAs phase in: South Waikato, Ruapehu

2012: Service interruption in 4 TLAs due to termination of provider contracts in June 2012: Porirua, Waitakere, Opotiki, Papakura.

2015: With no further expansion of the programme after 200507, 44 TLAs where Family Start had never been made available.

Box 1. Timeline of Family Start Expansion

Family Start workers developed individualised plans with families and whānau that were the basis for the services and support provided. 
Workers actively connected caregivers to other helping agencies and worked to promote engagement with child health and early childhood education services. Family Start workers were expected to work with around 16 families or whānau at a time (Family and Community Services, 2009). Table 1 outlines the activities workers undertook over the period studied and the shorter and longer term outcomes sought.

Table 1. Family Start Programme Logic

\begin{tabular}{|c|c|}
\hline Activities & $\begin{array}{l}\text { Family Start workers: } \\
\text { engage families and conduct regular home visits } \\
\text { work in partnership with families to achieve their goals and improve outcomes for } \\
\text { the child } \\
\text { develop and regularly review individualised family plans } \\
\text { promote access to and use of child health services and early childhood education } \\
\text { deliver the Āhuru Möwai/Born to Learn curriculum } \\
\text { provide caregivers with social, emotional and practical support } \\
\text { support caregivers to ensure babies are breastfed, reduce hazards in the home and } \\
\text { keep the home smoke free } \\
\text { support caregivers to address family violence, substance abuse, mental health, } \\
\text { housing, income support, budgeting and other difficulties } \\
\text { work collaboratively with other agencies to address families' needs and promote } \\
\text { access to services } \\
\text { move families to greater independence by promoting improved confidence and } \\
\text { connectedness with family/whānau and community } \\
\text { report to Child, Youth and Family (CYF) where there are concerns about child abuse } \\
\text { or neglect }\end{array}$ \\
\hline $\begin{array}{l}\text { Short- } \\
\text { medium } \\
\text { term } \\
\text { outcomes }\end{array}$ & $\begin{array}{l}\text { Family Start increases the likelihood that: } \\
\text { Well Child/Tamariki Ora health checks are completed } \\
\text { children are registered with a primary health care provider } \\
\text { children are registered with an oral health practitioner } \\
\text { immunisations are up-to-date } \\
\text { babies are breastfed } \\
\text { homes and cars are smoke free and free of hazards } \\
\text { children are healthy, physically safe and not maltreated } \\
\text { children participate in early childhood education } \\
\text { caregivers have an understanding of child development and provide warm, } \\
\text { sensitive, consistent and competent care for their children } \\
\text { family violence and alcohol and drug misuse that impacts on children is identified } \\
\text { and addressed } \\
\text { depression and other mental health problems are identified and addressed } \\
\text { families have stable housing and basic needs are met }\end{array}$ \\
\hline $\begin{array}{l}\text { Ultimate } \\
\text { outcomes }\end{array}$ & $\begin{array}{l}\text { children's health, education and social outcomes are improved } \\
\text { parenting capability and practice are improved } \\
\text { parents' personal and family circumstances are improved }\end{array}$ \\
\hline
\end{tabular}




\section{Āhuru Mōwai and Born to Learn}

Āhuru Mōwai and Born to Learn was the Family Start child development and parenting curriculum used during the period covered by the impact evaluation. ${ }^{8}$ The roots of Born to Learn go back to the Missouri Parents as Teachers Home Visiting programme that was introduced into Aotearoa New Zealand in 1992 as 'Parents as First Teachers' (Farquhar, 2003). This imported curriculum met with criticism and in 1996, after some initial superficial efforts to make it more culturally responsive, ${ }^{9}$ the Early Childhood Development Unit Manager for Māori brought a working group together to develop a Māori overlay_Āhuru Mōwai. This development continued until 1998, after which time two separate but interconnected directions emerged (Early Childhood Development Unit, 1999a). The first direction was the collation of ideas and activities to enhance child development from a Māori cultural base (see Figure 2 for an example). The second direction was the collation of traditional Māori knowledge and understandings that were directly related to the strands and principles of the Te Whàriki: He Whäriki Màtauranga mō ngā Mokopuna o Aotearoa-Early Childhood Curriculum ${ }^{10}$ (Ministry of Education, 1996). This connected Āhuru Mōwai to a New Zealand designed and developed framework.

Adaptations made by the Early Childhood Development Unit ensured consistency with Te Whāriki, and relevancy to the social and cultural context of Aotearoa New Zealand (Farquhar, 2003). The curriculum from this point forward was called Āhuru Mōwai and Born to Learn. The Âhuru Mōwai overlay drew on the ancient teachings of Māori ancestors with regards to "Papatūānuku—earth mother" and "Te Whare Tangata-the house of humanity". These kaupapa are central to teaching and learning about the importance of wāhine, tāne, and whānau and their roles in protecting and nurturing tamariki to provide the best possible chance of a healthy, strong 
growth period within the womb, a good birth, and ongoing guidance throughout life. This symbolism was reflected in the logo for Āhuru Mōwai and Born to Learn, designed in 1999 by Anakura Taumaunu, of Ngāti Porou and Ngāi Tahu tribal descent (Figure 2).

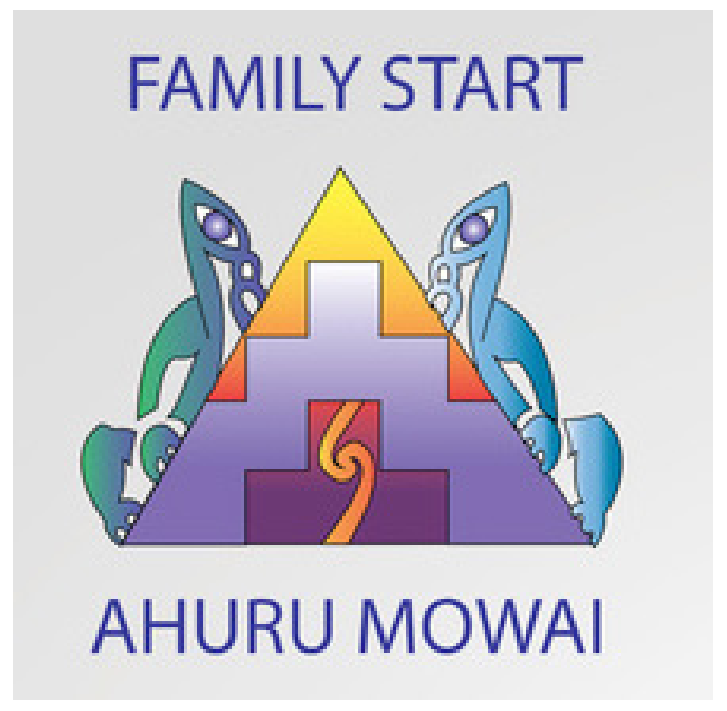

Figure 2. Āhuru Mōwai Logo

It is important to emphasise that intrinsic to Āhuru Mōwai were positive Māori tikanga and practices.

Translated, Āhuru means "to shelter", but not just any kind of shelter, it pertains to the shelter of the womb. Āhuru Mōwai refers to the "sheltered abyss of the womb, te whare tangata, a place of perfection, complete with the essential elements required to sustain the beginnings of life" (Early Childhood Development Unit, 1999a). Āhuru Mōwai resources and training emphasise Te Whare Tangata, literally meaning the house of people, and 
brings in another traditional concept, or kōrero tawhito, related to caring for and respecting woman and their role as mothers.

Women were considered tapu or sacred during pregnancy, and they were regarded in high esteem as the seedbed of future generations and henceforth the survival of the whānau, hapū and iwi. The children were considered precious taonga (treasures) and were cared for and nurtured by the whole whānau including the extended whānau or hapū.

The Māori culture aligns women with land, in kōrero tawhito Papatūānuku, the earth mother brings forth life supported by the sustenance of the sun, Ranginui, and the elements. Women bring forth life that has been nurtured within their whare tangata (womb) and sustenance provided by the breast, te wai $\mathrm{u}$; both mother and pēpi are then supported and protected by the father or pāpā.

This philosophy encourages a balance of the physical, intellectual, spiritual, natural and family elements required to support the ongoing growth and development of children.

The Āhuru Mōwai philosophy was given practical application through the Te Mahere Kaupapa Māori activity resource. The first draft was published in 1999 (Early Childhood Development Unit, 1999c) and over time was trialled, added to, and reformatted.

Te Mahere Kaupapa Māori promoted and encouraged the use of Māori cultural resources. One Family Start provider created a Māori Resource Kete (basket) specifically to support its cultural delivery. ${ }^{11}$ The Kete included child appropriate and safe cultural resources (poi, ti rakau, tititorea, seriated raurau, seriated kete, various harakeke woven shapes, seriated various anga, pohatu, taonga puoro, pukapuka and puzzles in te reo Māori that included themes of native birds, plants and Māori patterns). 
As well as cultural resources, Te Mahere Kaupapa Māori promoted and encouraged the use of natural resources (shells, sea-weed and sand from Tangaroa, leaves, bark and seeds from Tāne Mahuta, hue, uku and pohatu from Papatūānuku). These resources supported a link to Atua Māori and hence enabled a broader scope of discussion. Linking to Atua Māori provided opportunities for whānau workers to discuss whakapapa traits, tuakana and teina relationships and to talk about whānau in a universal sense with the Family Start families.

The Māori Resource Kete was reproduced numerous times to meet demand from Family Start providers. Te Mahere Kaupapa Māori provided an option for whānau workers; it gave them guidance to be able to tailor their delivery to whānau who preferred and/or better engaged with a service that incorporated and supported their Māori culture.

Box 2. Te Whare Tangata, Āhuru Mōwai, and the Te Mahere Kaupapa Māori resource

Āhuru Mōwai was launched in August 1999 at Te Hirangi Marae in Turangi by Dr Rangimarie Rose Pere CBE, a world-renowned Māori knowledge holder. Born to Learn and the Āhuru Mōwai overlay, philosophy, and logo were then presented at mandatory induction training for all new Family Start whānau workers. A specialised training team was employed by the Early Childhood Development Unit and then the Ministry of Education to develop and facilitate Āhuru Mōwai induction and ongoing training support for Family Start.

Two other awa enable a fuller understanding of the context in which Family Start was operating; namely, whānau ora and associated measures of whānau wellbeing, and indigenous home-visiting initiatives operating elsewhere. 


\section{Whānau Ora and measures of whānau wellbeing}

The concept of whānau ora, or Māori family wellbeing, was introduced into the government policy lexicon in 2002 in the Ministry of Health's Māori Health Strategy, He Korowai Oranga (Ministry of Health, 2002). Whānau ora was defined in this strategy as "Māori families supported to achieve their maximum health and wellbeing" (p.1), with this including their holistic health and wellbeing, their participation in te ao Māori (the Māori world) and te ao hurihuri (the non-Māori world), and them living longer and better quality lives. The strategy was clear that whānau ora was more attainable when whānau were supported, cohesive, secure in their identity and confident, safe, and had the social, economic, and physical means to provide for themselves. These concepts were reiterated across the whole-of-government when the Taskforce on Whānau-centred Initiatives (2010), established by Dame Tariana Turia when she was a member of Parliament, reported on their consultation with Māori about Whānau Ora. What followed this report was the introduction of the Whānau Ora approach to delivering social services.

Although the Taskforce's (2010) report said little about the wellbeing of babies and young children, the Whānau Ora initiative and its accompanying budget gave Māori "providers from the health and social service sectors... a formal mandate to work across traditional sector boundaries in a cooperative and collaborative manner and place whānau and whānau needs at the centre of any and all care plans" (Boulton, Tamehana, \& Brannelly, 2013, p. 19). Like Family Start, Whānau Ora is about working with whānau to deliver a culturally responsive service that starts from where whānau are at.

Alongside the development of the Whānau Ora initiative, developments in national data collection and reporting strengthened the infrastructure for the study of Māori expressions of whānau and measures of wellbeing that align with Māori values and priorities (Tibble 
\& Ussher, 2012; Kukutai, Sporle \& Roskruge, 2016; Kukutai, Sporle \& Roskruge, 2017), with a first Māori social survey-Te Kupengacarried out in 2013 and scheduled to be repeated in 2018. However, linked government administrative data, at the time of this writing, offered no measures of whānau, or whānau wellbeing (Kukutai, Sporle \& Roskruge, 2017).

\section{Indigenous home-visiting programmes}

Lessons about the potential impact of Family Start on the wellbeing of young whānau (i.e., whānau with babies and young children) can be drawn from the outcomes of other indigenous home-visiting programmes. Mraz Esposito and colleagues (2014) undertook a systematic review of the international evidence on the effectiveness of home-visiting programmes targeted at indigenous pregnant women or families with children under 5 years of age (known as the HomVEE (Home Visiting Evidence of Effectiveness) review). Family Spirit was the one programme (out of 28 reviewed) in the review that met all the review's criteria for effectiveness. Family Spirit is a culturally congruent, family-strengthening, American Indian home-visiting programme that has been shown to increase adolescent mothers' maternal involvement and knowledge of child care. Participation in the programme was associated with mothers' positive maternal role attainment (i.e., embracing child care) and having a positive maternal self-image. Barlow et al. (2006) concluded that random control trial results reflected the dual focus of Family Spirit on improving parenting and addressing the mothers' behavioural or mental health risks that might impinge on her parenting. Clients of indigenous home-visiting programmes report that they greatly value the relationship they have with their home visitor (Clapham, BennettBrook, \& Lawrence, 2015). The home visitors are described by clients as warm, nonjudgemental, honest, friendly and good listeners (Sivak, 
Arney, \& Lewig, 2008) (see Figure 3). Gerlach (2015) described this as part of the development of a relational process of knowing, where home visitors learn from families and communities through interpersonal inquiry that is shaped by home visitors' own identity and lived experiences. In a similar vein, Mildon and Polimeni (2012) concluded that programmes that do not have a strong focus on relationship building are unlikely to work for indigenous families.

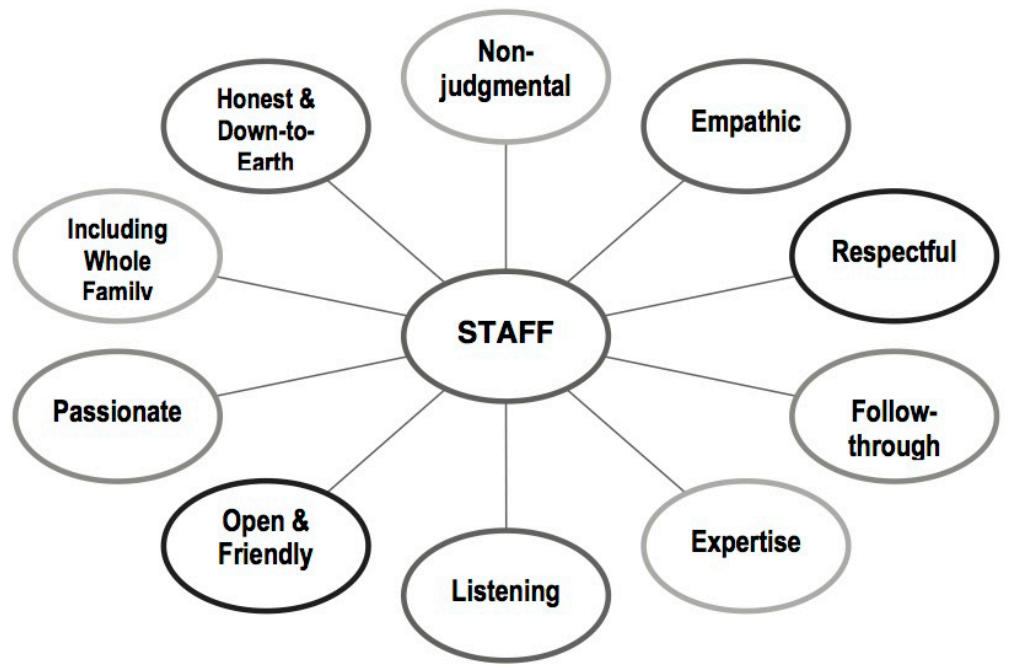

Figure 3. Characteristics of Family Home Visiting Staff

(Source. Sivak, Arney, \& Lewig, 2008, pp. 24, Figure 3)

\section{The impact evaluation ${ }^{12}$}

The impact evaluation used de-identified linked administrative data for children born in the years 2004-2011. ${ }^{13}$ Ethics approval for use of the data for the study was granted by the Central Health and Disability Ethics Committee (Reference 14/CEN/95).

Two separate quasi-experimental methods were applied to the data. The first method was applied at the individual level. Children 
born in 2009-2011 who enrolled in Family Start in the areas newly served in the 2005-07 expansion were matched with children who shared similar characteristics but were resident in areas where Family Start was not available at the time. ${ }^{14}$ This matching took account of a "propensity score" that captured the likelihood that whānau would have enrolled in Family Start if it had been offered in their area. The impact of the programme was estimated by comparing outcomes for the two groups of matched children.

The second method was applied at the community level and estimated whether there were changes in outcomes that were associated with the timing of the introduction of Family Start into new areas in the 2005-07 expansion of the programme. This was done looking only at the population of children supported by welfare benefits at around the time of their birth in each community. An estimated $70 \%$ of children enrolled in Family Start were supported by welfare benefits at around the time of their birth, and families could qualify based on low income alone during the period studied (although in practice most qualified on multiple criteria (Ministry of Social Development, 2009)).

The individual-level method can be thought of as estimating the average impact of the programme on those who were enrolled in it, and the community-level method estimates the impact of offering the programme at the community level on all children born into families supported by benefits in that community, regardless of whether they enrolled. An advantage of the community-level method was that it captured potential spillover effects on other people living in the same community (for example, the children of other whānau members and subsequent children born to mothers who had received Family Start when their older children were born).

Impacts were estimated for Māori children, for Pacific children, and for children overall. Ethnicity was derived using 'total response' 
ethnic data (Statistics New Zealand, 2005) reported by the parents on the birth registration. ${ }^{15}$ A child was viewed as Māori if any of the ethnic groups recorded for them was Mãori. Outcomes considered were limited to those that could be measured in the available linked administrative data and that linked to the programme logic in Table 1.

\section{Indigenous data sovereignty}

The final knowledge system drawn upon is an emerging one. It relates to new discussion and debate relating to indigenous data sovereignty in the context of 'big data'. Snipp (2016) reports that growing indigenous concerns about the monitoring and surveillance of their communities have accompanied the increased availability of "big data" that contains indigenous information. This is not to say that indigenous peoples are anti-science, despite long histories of often poor relationships with nonindigenous researchers (Mead, 2003; Smith, 2012). The Preamble to Te Mana Raraunga-the Māori Data Sovereignty Network Charter, for example, asserts that "[d]ata is a living tāonga [treasure] and is of strategic value to Māori" (Māori Data Sovereignty Network, 2016). Indigenous peoples merely want to ensure their meaningful participation in decisions being made about linked administrative data and other forms of big data to ensure that the data itself, the research using it, and the actions subsequently taken based on findings are compatible with and facilitate indigenous aspirations (Kukutai \& Taylor, 2016). These aspirations include the fulfilment of the rights of indigenous peoples (United Nations, 2007).

\section{Whiria-the braiding}

Braiding across knowledge streams offered new perspectives on the impact evaluation's results for Māori, the role of Māori provider 
organisations in service delivery to Māori, the limitations of the evaluation, and the implications of the indigenous data sovereignty movement.

\section{New perspectives on study results for Māori}

The most striking finding from the impact evaluation was evidence that Family Start reduced post-neonatal mortality. Effect sizes were larger for Māori children than for the study sample overall. Results for Māori children from the individual-level method showed that children who were enrolled in Family Start had significantly lower mortality than matched children in areas where Family Start was not available, with significant reductions in all-cause post-neonatal infant mortality, and in post-neonatal Sudden Unexplained Deaths in Infancy (SUDI) and injury deaths, and reductions in all-cause and injury mortality in the second year of life. Community-level estimates also showed a statistically significant reduction in post-neonatal infant mortality for Māori. Community-level impacts on SUDI and first-year injury deaths effects were not statistically significant. Mortality results are of interest because infant mortality rates are high in this country compared to other OECD countries (Simpson, Duncanson, Oben, Wicken, \& Pierson, 2015). Rates of SUDI are especially high, particularly for Māori infants (NZ Mortality Review Data Group, 2014).

Box 3 describes a range of robustness checks that were applied to see whether SUDI prevention activities over the period of study, rather than Family Start, might account for the results. The results were robust to these checks. In practice, Family Start and SUDI prevention efforts should perhaps not be viewed as competing explanations, but rather as working in combination. Family Start providers were among the first organisations to start distributing wahakurahand-woven flax bassinets aimed at promoting safe sleeping-to 
whānau (Vette, personal communication February 22, 2017). In 2015, 9 out of the 10 Family Start providers in the impact study that were in a set of district heath boards directed to work towards SUDI prevention responded to a short survey about SUDI prevention activities in their areas. All but one responded that they helped distribute wahakura or Pēpi-Pods-low cost bassinets made from plasticto promote safe sleeping. And all but one reported that they had received training in safe sleep practices (Vaithianathan et al., 2016, Appendix D). Family Start offers a point of connection with highrisk families, and a means to disseminate public health messages and resources to families and whānau who would otherwise find it hard to access these supports.

Nationally, rates of all-cause post-neonatal infant deaths were very gradually trending downwards over the 2004-2011 period during which the study cohorts were born, and fell steeply in 2012, the last year in which study cohort members passed through infancy. The decline in all-cause post-neonatal deaths was partly driven by a reduction in SUDI that was most marked for Māori infants (NZ Mortality Review Data Group, 2014).

An important question is whether there were other changes occurring during in the study period with the potential to disproportionately reduce infant mortality in areas that newly received Family Start as part of the 2005-07 expansion. Rather than being the result of Family Start, could the estimated infant mortality reductions reflect the impact of SUDI prevention initiatives? These initiatives included, but were not limited to, the following. 
- From 2006 safe shared sleeping was promoted through provision of wahakura targeted to high-risk families in a number of district health boards (DHB)s. These efforts were on a relatively small scale. The cost of producing wahakura was a limiting factor (Abel \& Tipene-Leach, 2013).

- In 2009, a "blitz" approach to SUDI education was introduced (Mitchell, Cowan, \& Tipene-Leach, 2016).

- In 2010 the Ministry of Health directed 8 DHBs to work on SUDI prevention as part of a Māori Health Strategy. Three DHBs (Counties Manukau, Waikato and Hawkes Bay) were particularly active in their response.

- In 2011, Change for our Children distributed 1,000 PēpiPods in the Christchurch area to families with infants affected by the February 2011 earthquake, and in 2012 (the last year of infancy for the quasi-experimental study cohorts) began distribution on a larger scale to organisations nationwide (Cowan, 2015).

As a result of SUDI prevention efforts, tailoring of SUDI prevention messages to Māori and high-risk families was improved, and distribution of Peppi-Pods and wahakura appear to have allowed culturally valued shared sleeping behaviours to continue in a safer way (Abel \& Tipene-Leach, 2013; Best Practice Journal, 2013; Cowan, 2015; Mitchell, Cowan, \& Tipene-Leach, 2016).

A number of different robustness checks were applied in the impact evaluation to assess whether these efforts could explain the study results. 
- The community level method was restricted to include only TLAs within the eight DHBs that were directed to undertake SUDI prevention activities in 2010.

- The community level method was re-estimated excluding children born in 2010 and 2011 in order to minimise overlap with the period following the post-2009 SUDI education initiative, the 2010 Ministry of Health directive and the beginning of national Pēpi-Pod distribution.

- The individual level method was reapplied excluding the Waikato DHB (which was one of the most active in implementing SUDI prevention initiatives).

In each case, results showing an association between Family Start and reduced mortality remained.

Box 3. SUDI Prevention Efforts as a Competing Explanation

Mortality results from the study are promising. They are consistent with evidence from studies of home-visiting programmes in the United States (Olds et al., 2014; Carabin et al., 2005) and from examination of the mortality effects of introduction of nurse home visits on a universal basis in Europe (Wüst, 2012). One tribal home-visiting programmes in the HomVEE review (Mraz Esposito et al., 2014) focused on the reduction of infant mortality. This programme encouraged American Indian women in Wisconsin into prenatal care, and visited with women twice-once before baby was born and once again afterwards. No preterm or low birthweight babies were born, and no infants died for the women who participated in this intervention (Davis \& Prater, 2001; Prater \& Davis, 2002). At least two of the factors described as contributing to the success of this programme can also be found in Family Start; namely, 
use of a culturally responsive "logo to identify the program [and] helpful and culturally sensitive staff" (Davis \& Prater, 2001, pp. 12-13). Although Davis and Prater (2001) described a lack of nurturing among mothers, with the programme often referring mothers to a separate nurturing programme, the Āhuru Mōwai and Born to Learn curriculum was delivered as part of Family Start to support parenting and nurturing.

Like the Early Start randomised controlled trial (Fergusson et al., 2012), findings from the individual-level method applied in the Family Start impact evaluation indicated positive impacts on connection to some health services. Compared to the matched control group, Māori children who received Family Start had a higher likelihood of being fully up-to-date with immunisations in their first 2 years, and their mothers appeared more likely to use addiction services. These findings are also compatible with other indigenous home-visiting programmes (Barlow, et al., 2015; Davis \& Prater, 2001). Family Start appears to strengthen the connection between young whānau and other services, and motivate and support mothers to tackle difficult issues in their own lives.

A concerning finding was that Family Start children were less likely to be enrolled with a primary health organisation (PHO) at age 1 than the matched control group. This was seen in overall results and for Māori children. This may signal that the trust relationship between a Family Start worker and young whānau takes time to build, or that the worker is able to answer health queries that might otherwise motivate whānau to enrol in a PHO (yet see below, Māori Provider Organisations and Other Providers, for a more nuanced finding). By age 2 there was no evidence of a negative impact on $\mathrm{PHO}$ enrolment in overall results, and Māori children who received Family Start were in fact more likely to be enrolled with a $\mathrm{PHO}$ than Māori children in the matched control group. No statistically 
significant impacts on health-service engagement were found using the community-level method.

The Family Start study highlighted the difficulty in using administratively sourced measures to assess whether abuse and neglect is reduced because of a home-visiting programme. The presence of a worker in the home could result in higher rates of referral to child-welfare agencies and higher rates of presentation at hospital, and this could offset the effects of any real decrease in harm on levels of agency contact (Fergusson et al., 2012; Gilbert, et al., 2012). Administrative measures could show no change, or even an increase in agency contact. Individual-level results for Māori children showed no statistically measurable impact on hospitalisation for maltreatment-related injury. However, there was a statistically significant reduction in hospitalisation for long bone fractures in infancy. Long bone fractures are considered a possible marker for intentional injury (Gilbert, et al., 2012), and this result hints at the possibility of improved child safety because of Family Start.

Children who received Family Start were more likely to come to the early attention of Child Youth and Family (CYF) child-welfare services compared to the matched control group. The magnitude of the effect was difficult to establish. For example, some children had entered Family Start because of earlier CYF involvement, and this resulted in "reverse causality" inflating some of the estimated effects. Estimates from the community-level method, which would not be affected by reverse causality, showed a statistically significant increase in the proportion of Māori children supported by benefit who had substantiated findings of emotional abuse in their first year of life. This may indicate increased attention being paid to family violence because of Family Start. When family violence referrals are investigated, any substantiated findings recorded in relation to children present are often categorised as emotional abuse (Ministry of 
Social Development, 2012). It appears likely that the presence of the Family Start worker in the home, and increased contact with other services because of Family Start, made it more likely that concerning behaviours and circumstances were identified and brought to the early attention of CYF. Studies of other home-visiting programmes have also suggested the existence of such "safeguarding" effects (Fergusson, Grant, Horwood, \& Ridder, 2005; Robling, et al., 2016; Tufts Interdisciplinary Evaluation Research, 2015). ${ }^{16}$

\section{Māori provider organisations and other providers}

Using the individual-level method, a follow-up to the main study examined impacts for Māori children who enrolled in Family Start according to whether they were served by Māori provider organisations or by other providers. The follow-up study focused on a subset of outcomes that were unambiguous in their interpretation (Vaithianathan, Maloney, Wilson \& Joyce, 2017). Māori provider organisations were defined as including those that were operated by an iwi, or a marae, Māori trust, Māori authority, or Whānau Ora collective. Compared to mainstream (non-Māori) organisations, Māori provider organisations often have a focus on developing tribal capability, capacity and connections (Boulton et al., 2013; Pipi, et al., 2002). Many Māori Family Start provider organisations are likely to have had this focus, in addition to the Family Start focus on the wellbeing of children and families.

Reductions in post-neonatal mortality found in the main study held for Māori children served by both Māori and non-Māori providers. Increases in rates of full immunisation were found for Māori children served by Māori providers, but not Māori children served by other providers. Where results for Māori children overall had shown reduced $\mathrm{PHO}$ enrolment at age 1 (but increased $\mathrm{PHO}$ enrolment at age 2, see above), for Māori children who received Family Start from 
Māori provider, $\mathrm{PHO}$ enrolment at age 1 was increased. A possible explanation for positive immunisation and $\mathrm{PHO}$ enrolment results for Māori children in families served by Māori providers is improved co-ordination of services where the same organisation provided Family Start and Well Child/Tamariki Ora or other health services, suggested in a study of programme alignment (Davies, 2013).

With the expansion of Whānau Ora, Māori and other organisations providing Family Start and Whānau Ora services can now combine funding streams to deliver a more holistic service to whānau. This is important given that indigenous home-visiting programmes are often faced with difficulties delivering programme content in the face of families' more immediate needs (Mraz Esposito et al., 2014; Martin, 2014). As Davis and Prater (2001, p. 14) observe for their home-visiting programme with Native American women and families in Wisconsin, "[f]ood, shelter, and safety had to be considered first." Māori providers often combine a number of separate contracts from a range of funders, and are required to work innovatively to mobilise resources around whānau (Boulton et al., 2013). Understanding the ways that providers integrate programmes from different funding sources, and how Family Start interfaces with Whānau Ora and other services, is an important topic for further research.

\section{New perspectives on the limitations of the study}

The report on the impact study identified several study limitations (Vaithianathan et al., 2016), including a lack of any direct measures in the available administrative data of the home environment, parenting attitudes and behaviours, or children's development and cognition. Our examination of the findings for Māori whānau has brought an additional cultural lens to consideration of this limitation. Although only some outcomes could be considered using linked administrative data, the mortality results are compelling. Although 
child mortality is a deficit indicator, its inclusion focuses policy attention on children and whānau who are less well-off in our society (OECD, 2009). However, we learn nothing about whānau capabilities we might strengthen to ensure everyone's wellbeing (Tauli-Corpuz, 2016). Based on their analysis of data in Te Kupenga, Kukutai et al. (2017, p. 53) conclude that "efforts to support whānau to thrive will...involve supporting individual whānau members to live their lives in a way that is meaningful and that gives them satisfaction." A key limitation of the impact study was that it did not investigate a range of outcomes valued by Māori.

Another was the limited view the study had of the centrality of Āhuru Mōwai and Born to Learn and the accompanying resources to the delivery of Family Start to Māori. A number of possible mechanisms were suggested in the study report as possible explanations for the positive impacts on childrens survival. To these should be added the role that Āhuru Mōwai and Born to Learn played in engaging parents of Māori infants in the programme, and supporting positive parenting. From the perspective of Vette, a former manager of two Family Start sites, the Āhuru Mōwai logo was a valuable tool for introducing families to the programme. It helped whānau workers explain the child-centredness of the programme and gain the parents' consent and commitment. Knowing how to use kaupapa Māori frameworks increased the ability of workers to deliver Family Start in a bicultural manner, with respect for the mauri of the whole whānau. Māori and non-Māori Family Start providers embraced Āhuru Mōwai, and connected with the visual representation and the depth of knowledge the logo symbolised. Twenty-one caregivers interviewed as part of a 2014 evaluation were consistently positive about their experiences of Family Start, and particularly valued Āhuru Mōwai and Born to Learn. They articulated the increased awareness of the importance of parenting practice that they gained from the curriculum (Martin, 2014). 


\section{Reflections on linked administrative data}

Linked administrative data in Aotearoa New Zealand contain information on Māori (and non-Māori) engagement with and outcomes from government-funded services, including health, income support, and child-welfare services. Such data are seen as an important new resource, with the potential to inform improvements in service design and delivery, and support better matching of service delivery with need (Currie, 2013; Hughes, 2015; Macchione, Wooten, Yphantides, \& Howell, 2013; New Zealand Data Futures Forum, 2014; Putnam-Hornstein, Wood, Fluke, Yoshioka-Maxwell, \& Berger, 2013; Vaithianathan, et al., 2012; Vaithianathan et al., 2013). Among the first Aotearoa New Zealand studies to use extensively linked administrative data relating to children was a feasibility study that examined a proposal for predictive modelling using linked data to be used as part of efforts to prevent child maltreatment (Wilson, Tumen, Ota, \& Simmers, 2015; Wilson \& Cram, in press). Two reviews identified ethical and privacy risks associated with the proposal (Blank, et al., 2014; Dare, 2014). The "Dare Review" proposed that many of these risks could be mitigated in the implementation. The Māori review was concerned that the data being used did not capture the full reality of being Māori (also see above), and that there was a risk of codifying structural determinants of child maltreatment as personal deficits. Moreover, this review and the feasibility study identified the risk that predictive modelling would overpredict Māori child maltreatment and result in hypersurveillance of Māori whānau (Blank, et al., 2014; Wilson et al., 2015; Wilson \& Cram, in press). A subsequent collaborative investigation of the potential for hypersurveillance did not resolve these issues, and urged caution in using and interpreting administrative data (Cram, Gulliver, Ota, \& Wilson, 2015). 
The Family Start impact study adds to the conversation the potential to use linked administrative data to understand the impact of a programme that aims to improve outcomes for whānau. Consensus that using linked administrative data for a purpose of this nature is in the public interest might be more readily reached. All parties are interested in knowing if an initiative works so that they can spend their resources and efforts in a way that makes a positive difference (New Zealand Data Futures Forum, 2014; Advisory Group on Conduct Problems, 2011). Although, as Hudson (2016) notes, even if Māori and the government are interested in the same questions, the answers they come up with may be quite different. Although linked administrative data enabled researchers to ask questions about the impact of Family Start on whānau, he awa whiria provided a useful platform for drawing together the different knowledge streams (ngā awa) needed to interpret the answers. This metaphor holds promise for supporting Māori engagement with growing use of linked administrative data. Our findings support the view that Family Start plays an important role in supporting the wellbeing of whānau. They endorse the expansion of Family Start to all regions that occurred in 2016 and 2017, and re-emphasise the importance of efforts to ensure the cultural responsiveness of the programme as it expands and evolves, to Māori and to other client groups.

\section{Conclusion}

In this article we asked whether the metaphor of he awa whiria could facilitate shared reflections on an impact study that used linked administrative data, where our questions were about if and how Māori benefitted from Family Start. In our group's wānanga he awa whiria was conceptualised within a Māori paradigm so that tikanga and kaupapa were intrinsic to the thinking and, in this way, mātauranga 
Māori was to the fore. Different perspectives on the history of Family Start, the impact study, the international literature about home-visiting programmes for indigenous peoples, an emerging literature on indigenous data sovereignty and other braids were visualised as connecting, crossing over and wrapping around one another within an awa whose whaiawa was mātauranga Māori. This allowed the group to draw in knowledge of kaupapa Māori delivery mechanisms such as Āhuru Mōwai, and include te reo Māori me ōna tikanga as naturally as possible throughout discussions about the impact evaluation.

We are in agreement with Mason Durie (2004, p. 1139), that "[a]rising from the creative potential of indigenous knowledge is the prospect that it can be applied to modern times in parallel with other knowledge systems." At the same time, we have been pragmatic that the starting point for this analysis is somewhat downstream in a proper data sovereignty journey. None of us have had any control over the nature of the data collected, and to date administrative data shine greater light on the reduction of risks than improvements in wellbeing. However, we share a commitment to understanding Family Start's outcomes for whānau because we support the attainment of whānau ora by whānau who live in difficult and challenging circumstances.

\section{Acknowledgements}

The original research reported on here was supported by funding from Community Investment, Ministry of Social Development (MSD) and in-kind contributions from the Auckland University of Technology (AUT) and MSD. The present article was supported by funding provided by Oranga Tamariki and in-kind contributions from Oranga Tamariki and MSD. The authors gratefully acknowledge the assistance and advice provided by the many people who helped at different stages of the overall project. 


\section{Disclaimer}

Access to the data used in this study was provided by Statistics New Zealand (SNZ) under conditions designed to give effect to the security and confidentiality provisions of the Statistics Act 1975. The results presented in this study are the work of the authors, not SNZ. The views expressed are those of the researchers. They do not necessarily reflect the position of MSD, Oranga Tamariki, or those involved in the advisory or review processes. MSD and Oranga Tamariki have made every effort to ensure the information in this report is reliable, but do not guarantee its accuracy and do not accept liability for any errors.

\section{Glossary}

Source. Te Aka Māori-English English-Māori Dictionary online (www.maoridictionary.co.nz), with translations given that are most relevant to the use of these words within this article.

Āhuru Mōwai

awhi rito

Aotearoa

awa

harakeke

he awa whiria

He Korowai Oranga

iwi

kaupapa

kaupapa Māori

mahere

Māori

mātauranga
Māori name for the Born to Learn programme, means a calm place, a sheltered haven, that pertains to the womb

leave the embrace the centre shoot of the harakeke, parents

New Zealand

river

New Zealand flax, Phormium tenax

braided rivers

Ministry of Health's 2002 Māori health strategy tribe agenda, theme

a Māori way

plan, map

Indigenous peoples of Aotearoa New Zealand

Māori knowledge 
marae

the open area in front of the wharenui, where formal greetings and discussions take place. Often also used to include the complex of buildings around the marae

mauri life force, vital essence

ngā awa more than one awa

Papatūānuku Earth mother, wife of Ranginui-Sky father pēpi baby, infant

raranga weaving

rito centre shoot, young centre leaf of the harakeke tamariki children

tāne men

tangata whenua people born of the land, indigenous people te ao hurihuri modernity, the non-Māori world te ao Māori the Māori world Te Mana Raraunga Māori Data Sovereignty Network Charter Te Puni Kōkiri Ministry of Māori Affairs te reo Māori me ōna tikanga Māori language and custom Te Whāriki New Zealand Early Childhood Curriculum te whare tangata the house of humanity, womb tikanga correct procedure, custom wahakura woven harakeke bassinet for infants wāhine women wānanga deliberations, forum whaiawa riverbed whānau extended family, family group whānau ora Māori whānau wellness wharenui meeting house whāriki floor covering, mat whiria weave 


\section{Notes}

1 All Māori-language terms and phrases are glossed in the Glossary section of this article.

2 The Māori term "he awa whiria" for this metaphor is used in the remainder of this article.

3 The 1990s was also a time when there was a shift in public sector management towards the contracting out of public services, alongside demand in health and social services for increased emphasis on Māori managing and delivering care for their own people (Cram, 2005; Ministerial Advisory Committee on a Māori Perspective for the Department of Social Welfare, 1988).

4 By July 2008, 63 percent of Family Start workers were qualified at diploma level or higher in social work, education or health, $25 \%$ were enrolled in study and 12 $\%$ were not qualified and not studying (Cribb, 2009). The proportion of Family Start workers with tertiary qualifications was $85 \%$ ( $81 \%$ in social work, $21 \%$ in education, and $17 \%$ in health-related fields — some had multiple qualifications) by 2014-15.

5 TLAs range from small provincial centres and their surrounding rural areas (with populations numbering in the thousands) to large urban centres (with populations numbering in the hundreds of thousands). Here, we refer to TLA boundaries as they were before the creation of the Auckland Super-city. In most cases, Family Start service boundaries map to 2006 TLA boundaries.

6 Five provider contracts across four TLAs were terminated under the new contracts in June 2012. Providers in another 11 TLAs were placed on one year contracts in response to performance requirements not being met.

7 For the evolution of guidelines and manuals, see Child Youth and Family, 1999; Family and Community Services, 2009; Family and Community Services, 2012; Community Investment, 2015.

8 The description of it here includes Vette's in-depth practice knowledge of its origins and development.

9 L. Tarrant, personal communication, February 20, 2017.

10 Whāriki is a woven flax or harakeke mat, symbolic of a strong foundation or framework on which to build. The principles and practice that underpin the process of raranga are also the basis of Māori conceptual and metaphoric practice models or frameworks (McRae-Tarei, 2013). The harakeke plant from which a whāriki is made is a treasure for Māori, and each part of this plant is symbolic and embodied with spiritual and cultural values. Traditionally, the fan of the 
harakeke plant represents the whānau; the rito, or middle shoot, being the pēpi, and the leaves on either side of it are the awhi rito, the parents. Some Family Start providers adopted harakeke as their logo to symbolise this model of whānau. Further reference to the harakeke plant as whānau is reflected in this well-known Māori proverb: Hutia te rito o te harakeke, Kei whaea te kōmako e ko? Kī mai ki ahau; He aha te mea nui o te Ao? Maku e kī atu, he tangata, he tangata, he tangata! If the heart of harakeke was removed, where will the bellbird sing? If I was asked, what was the most important thing in the world? I would be compelled to reply, it is people, it is people, it is people! (Author unknown)

11 Te Rūnanga o Ngati Porou Family Start had a Māori Resource Kete commissioned for its Family Start programme.

12 Vaithianathan et al., (2016) provide a full report on the impact study. Here we provide a high-level overview of the data and the methods used.

13 The linked dataset drew together information from a range of sources including Family Start enrolments, birth registrations, maternity, immunisation, mortality, welfare benefit and child welfare records, foreshadowing the Statistics New Zealand Integrated Data Infrastructure (NZIDI). The dataset available did not cover the very early implementation of Family Start (the 1998 establishment of the pilot sites and 1999-2000 expansion). It overlapped only slightly with changes to Family Start introduced in 2011 and 2012 and associated interruptions in service due to contract cancellations (because the evaluation was limited in focus to areas that newly received Family Start as part of the 2005-07 expansion, these interruptions affected only two of the areas studied-Papakura and Opotiki), and predated the introduction of Whānau Ora. The data did, however, cover the period of the enhancements to Family Start introduced in the mid-2000s, and the phased and incomplete expansion of that enhanced programme to new areas between 2005 and 2007. Variation in children's exposure to the programme because of their place of residence could be used as the basis for quasiexperimental estimation of programme impacts.

14 Data on which children enrolled in Family Start were only available from the end of 2008. For this reason, the individual level method could only be applied for cohorts born 2009-2011.

15 Where birth registration data were unavailable, ethnic groups recorded in maternity data were used.

16 Whether Māori children who enrolled in Family Start were more likely to have contact with CYF in the longer term (or whether the programme simply brought forward contact that would have occurred in any case), and whether 
increased contact before age 2 was preventive in that concerning behaviours and circumstances were addressed early on, could not be addressed in this study given the limited follow-up.

\section{References}

A Better Start National Science Challenge. (2015, March). E tipu e rea: Revised research and business plans. Wellington: A Better Start National Science Challenge.

Abel, S., \& Tipene-Leach, D. (2013, 2 August). SUDI prevention: A review of Māori safe sleep innovations for infants. The New Zealand Medical Journal, 126(1379). Retrieved from https:/www.nzma.org.nz/journal/ read-the-journal/all-issues/2010-2019/2013/vol-126-no-1379/view-abel

Advisory Group on Conduct Problems. (2011). Part 4: Te ao Māori perspectives on understanding conduct problems. In Conduct Problems: Effective Services for 8-12 year olds. Wellington: Ministry of Social Development.

Advisory Group on Conduct Disorders. (2013). Conduct problems: Adolescent report 2013. Wellington: Ministry of Social Development.

Barlow, A., Mullany, B., Neault, N., Goklish, N., Billy, T., Hastings, R., ... Walkup, J. T. (2015, February). Paraprofessional-delivered homevisiting intervention for American Indian teen mothers and children: 3 -year outcomes from a randomized controlled trial. American Journal of Psychiatry, 172(2), 154-162.

Barlow, A., Varipatis-Baker, E., Speakman, K., Ginsburg, G., Friberg, I., Goklish, N., ... Santosham, M. (2006). Home-visiting intervention to improve child care among American Indian adolescent mothers. Archives of Pediatrics and Adolescent Medicine, 160(11):1101-1107.

Berman, J., Edwards, T., Gavala, J., Robson, C., \& Ansell, J. (2015). He mauri, he Māori: Te iho, te moemoea, te timatanga ō mātou haerenga ki te ao tūroa / Our vision and beginnings of a journey into te ao tūroa (the world in front of us) in educational psychology. Psychology Aotearoa, 7(2), $100-105$. 
Best Practice Journal. (2013). Sudden unexpected death in infancy: Where are we now? Retrieved from http://www.bpac.org.nz/BPJ/2013/November/ infant-death.aspx

Blank, A., Cram, F., Dare, T., De Haan, I., Smith, B., \& Vaithianathan, R. (2014). Ethical issues for Māori in predictive risk modelling to identify new-born children who are at high risk of future maltreatment. Auckland: University of Auckland.

Boulton, A., Tamehana, J., \& Brannelly, T. (2013). Whānau-centred health and social service delivery in New Zealand. MAI Journal, 2(1), 18-32.

Carabin, H., Cowan, L. D., Beebe, L. A., Skaggs, V. J., Thompson, D., \& Agbangla, C. (2005). Does participation in a nurse visitation programme reduce the frequency of adverse perinatal outcomes in first-time mothers? Paediatric and Perinatal Epidemiology, 19(3), 194-205.

Child Youth and Family (1999). Family Start guidelines. Wellington: Child Youth and Family.

Clapham, K. F., Bennett-Brook, K. R., \& Lawrence, L. (2015). Evaluation of the Illawarra Aboriginal medical service safe homes, safe kids program: A home visiting program for Aboriginal families in an urban region. Wollongong: University of Wollongong Research Online.

Cognition Education. (2015). Health promoting schools: Unpackaging community development_Improving school communities' health, wellbeing, equity and educational outcomes. Wellington: Cognition Education.

Community Investment. (2015). Family Start programme manual. Wellington. Ministry of Social Development.

Cowan, S. (2015). Pēpi-Pod ${ }^{\oplus}$ programme: Materials for registered distributors - 2015. Christchurch: Change for our Children Ltd.

Cram, F. (2005). An ode to Pink Floyd: Chasing the magic of Māori and iwi providers. In J. S. Te Rito (Ed.), Tihei Oreore. Monograph Series-Policy Seminars, 1(2), pp. 15-26.

Cram, F., Gulliver, P., Ota, R., \& Wilson, M. (2015). Understanding overrepresentation of indigenous children in child welfare data: An application of the Drake risk and bias models. Child Maltreatment, 20(3), 170-182. 
Cribb, J. (2009). Review of Family Start and Early Start. Wellington: Ministry of Social Development.

Currie, J. (2013). "Big data" versus "Big brother": On the appropriate use of large-scale data collections in paediatrics. Pediatrics, 131, S127-S132.

Curtis, G., Reid, D., Kelley, M., Martindell, P. T., \& Craig, C. J. (2013). Braided lives: Multiple ways of knowing, flowing in and our of knowledge communities. Studying Teacher Education, 9(2), 175-186.

Dare, T. (2014). Predictive risk modelling and child maltreatment: An ethical review. Auckland: University of Auckland.

Davies, L. (2013). Improving alignment of Family Start and Well Child Tamariki Ora Services. Wellington: Ministry of Health.

Davis, C. L., \& Prater, S. L. (2001). A perinatal intervention program for urban American Indians part 1: Design, implementation, and outcomes. Journal of Perinatal Education, 10(3), 9-19.

Durie, M. (2004). Understanding health and illness: Research at the interface between science and indigenous knowledge. International Journal of Epidemiology, 33, 1138-1143. https://doi.org/10.1093/ije/dyh250

Early Childhood Development Unit. (1999a). Āhuru Mōwai. Wellington: Author.

Early Childhood Development Unit. (1999b). Ähuru Möwai staff training hui: Hirangi Marae, Turangi. Unpublished service document.

Early Childhood Development Unit. (1999c). Āhuru Möwai and Born to Learn curriculum: Te mahere kaupapa Māori. Wellington: Author.

Evaluation Management Group. (2003). Family Start process evaluation final report: A summary and integration of components of the process evaluation model. Wellington: Ministry of Education, Ministry of Health, and Ministry of Social Development.

Family and Community Services (2009). Family Start practice manual. Wellington: Ministry of Social Development.

Family and Community Services (2012). Family Start programme manual. Wellington: Ministry of Social Development. 
Farquhar, S. (2003). Parents as first teachers: A study of the New Zealand PAFT programme. Report prepared for Early Childhood Development Unit. Wellington: Ministry of Social Development.

Fergusson, D., Boden, J., \& Horwood, J. (2012). Early Start evaluation report: Nine year follow-up. Wellington: Ministry of Social Development.

Fergusson, D., Grant, H., Horwood, L. J., \& Ridder, E. (2005). Randomized trial of the Early Start programme of home visitation. Pediatrics, 116(6), e803-c809.

Fielding, K. (2011). Research to inform improvements to increase Family Start effectiveness in preventing child maltreatment and promoting child development. Unpublished. Wellington: Centre for Social Research and Evaluation, Ministry of Social Development.

Gerlach, A. (2015). Relational pathways in early intervention: Research summary report for the Aboriginal Infant Development Program of British Columbia. Vancouver, BC: Author.

Gilbert, R., Fluke, J., Izquierdo, A., Brownwell, M., Gulliver, P., Janson, S., \& Sidebotham, P. (2012). Child maltreatment: Variation in trends and policies in six developed countries. The Lancet, 379(9817), 758-772.

Hargreaves, K. (2012, November 14). Picture in article by Rachel Young: Ecosystems a treasure worth protecting. The Press. Retrieved from http://www.stuff.co.nz/the-press/news/7945868/ Ecosystems-a-treasure-worth-protection.

Hong, B., Arago-Kemp, V., Macfarlane, A., \& Poulton, R. (2015). He awa whiria-Braided rivers: Braiding across cultural paradigms. Presentation given at the Australasian Evaluation Conference.

Hudson, J. (2016). The world's most liveable city—for Māori: Data advocacy and Māori wellbeing in Tāmaki Makaurau (Auckland). In T. Kukutai, $\&$ J. Taylor (Eds.), Indigenous data sovereignty: Toward an agenda (pp. 179-191). Canberra: Australian National University Press.

Hughes, T. (2015). Predictive analytics for policy and practice reflections from the criminal justice system. Policy Quarterly, 11(2), 37-44. 
Irvine, P. (2003). Family Start: Its development, implementation and evaluation. Unpublished research paper.

Kukutai, T. Sporle, A. and Roskruge, M. (2016) Expressions of whānau. In Families and Whānau Status Report 2016. Wellington: Superu.

Kukutai, T., Sporle, A., \& Roskruge, M. (2017). Subjective whānau wellbeing in Te Kupenga. Wellington: Superu.

Kukutai, T., \& Taylor, J. (2016). Data sovereignty for indigenous peoples: Current practices and future needs. In T. Kukutai, \& J. Taylor (Eds.), Indigenous data sovereignty: Toward an agenda. Centre for Aboriginal Economic Policy Research, College of Arts and Social Sciences, The Australian National University, Canberra. Research Monograph No. 38 (pp. 1-22). Canberra: ANU Press.

Macchione, N., Wooten, W., Yphantides, N., \& Howell, J. R. (2013). Integrated health and human services information systems to enhance population-based and person-centered service. American Journal of Preventative Medicine, 45(3), 373-374.

Māori Data Sovereignty Network. (2016, May 9). Te mana raraunga-Māori Data Sovereignty Network charter. Retrieved from http://planetmaori.com/ Files/Content/2016/Te_Mana_Raraunga_Charter.pdf

Martin, M. (2014). How the Family Start programme is working for programme staff and for clients with high needs. Wellington: Ministry of Social Development.

McRae-Tarei, J. (2013). The sustainability of tikanga practice and values within toi raranga: Unpublished master's thesis, Auckland University of Technology.

Mead, H.M. (2003). Tikanga Mãori: Living by Mãori values. Wellington: Huia.

Mildon, R., \& Polimeni, M. (2012). Parenting in the early years: Effectiveness of parenting support programs for indigenous families. Canberra: Closing the Gap Clearinghouse. 
Ministerial Advisory Committee on a Maori Perspective for the Department of Social Welfare. (1988). Puao-te-ata-tu (Daybreak). Wellington: Author.

Ministry of Education. (1996). Te whäriki: He whäriki mätauranga mō ngā mokopuna o Aotearoa_Early childhood curriculum. Wellington: Learning Media.

Ministry of Health. (2002). He korowai oranga-Mäori health strategy. Wellington: Author.

Ministry of Social Development. (2009). Family Start 12 month performance report. Wellington: Author.

Ministry of Social Development (2012). Children's contact with MSD services. Wellington: Author.

Ministry of Social Development (2016). Family Start programme manual. Wellington: Author.

Mitchell, E. A., Cowan, S., \& Tipene-Leach, D. (2016). The recent fall in postperinatal mortality in New Zealand and the Safe Sleep programme. Acta Padiatrica, 105(11), 1312-20.

Mraz Esposito, A., Del Grosso, P., Kleinman, R., Sama-Miller, E., \& Paulsell, D. (2014). Assessing the evidence of effectiveness of home visiting program models implemented in tribal communities. Washington, DC:

Office of Planning, Research and Evaluation, Administration for Children and Families, U.S. Department of Health and Human Services.

New Zealand Data Futures Forum. (2014). New Zealand's data future: Full discussion paper. Wellington: Data Futures Partnership.

NZ Mortality Review Data Group. (2014). NZ Child and Youth Mortality Review Committee: 10th Data Report, 2009-2013. Dunedin: Author.

OECD. (2009). Doing better for children. Paris: OECD.

Olds, D. L., Kitzman, H., Knudtson, M. D., Anson, E., Smith, J. A. and Cole, R. (2014). Effect of home visiting by nurses on maternal and child mortality: Results of a 2-decade follow-up of a randomized clinical trial. JAMA Pediatrics, 168(9), 800-806. 
Paki, V., \& Peters, S. (2015). Exploring whakapapa (genealogy) as a cultural concept to mapping transition journeys, understanding what is happening and discovering new insights. Waikato Journal of Education-Te Hautaka Mãtauranga o Waikato, 20(2), 49-60.

Pipi, K., Cram, F., Hawke, R., Hawke, S., Huriwai, T. M., Keefe, V., . . . Tuuta, C. (2002). Mãori and iwi provider success: A research report of interviews with successful iwi and Mäori providers and government agencies. Wellington: Te Puni Kōkiri.

Prater, S. L., \& Davis, C. L. (2002). A perinatal intervention program for urban American Indians Part 2: The story of a program and its implications for practice. The Journal of Perinatal Education, 11(2), 23-32.

Putnam-Hornstein, E., Wood, J. N., Fluke, J., Yoshioka-Maxwell, A., \& Berger, R. P. (2013). Preventing severe and fatal child maltreatment: Making the case for the expanded use and integration of data. Child Welfare, 92(1), 59-75.

Robling, M., Bekkers, M.-J., Bell, K., Butler, C. C., Cannings-John, R., Channon, S., . . Torgerson, D. (2016, January 9). Effectiveness of a nurseled intensive home-visitation programme for first-time teenage mothers (Building Blocks): A pragmatic randomised controlled trial. The Lancet, 387(10014), 146-155.

Simpson, J., Duncanson, M., Oben, G., Wicken, A., and Pierson, M. (2015). Child Poverty Monitor 2015 Technical Report. Dunedin: NZ Child and Youth Epidemiology Service, University of Otago.

Sivak, L., Arney, F., \& Lewig, K. (2008). A pilot exploration of a family home visiting program for families of Aboriginal and Torres Strait Islander children. Report and recommendations: perspectives of parents of Aboriginal children and organisational considerations. Adelaide: Australian Centre for Child Protection.

Smith, L. T. (2012). Decolonizing methodologies—Research and indigenous peoples (2nd ed.). London, UK \& New York, NY: Zed Books. 
Snipp, C. M. (2016). What does data sovereignty imply: What does it look like? In T. Kukutai, \& J. Taylor (Eds.), Indigenous data sovereignty: Toward an agenda. Research Monograph 38 (pp. 39-55). Canberra: Australian National University Press.

Statistics New Zealand. (2005). Understanding and working with ethnicity data. Wellington: Author.

Superu. (2015). Frameworks to measure family and whänau wellbeing. Wellington: Author.

Superu. (2018). Bridging cultural perspectives. Wellington: Author.

Taskforce on Whānau-Centred Initiatives. (2010). Whānau Ora: Report of the Taskforce on Whānau-Centred Initiatives, to Hon. Tariana Turia, Minister for the Community and Voluntary Sector. Wellington: Author.

Tauli-Corpuz, V. (2016). Preface. In T. Kukutai, \& J. Taylor (Eds.), Indigenous data sovereignty: Toward an agenda. Research Monograph No. 38 (pp. xxi-xxiii). Canberra: Australian National University Press.

Tibble, A., \& Ussher, S (2012, October). Kei te pēwhea tō whānau? Exploring whànau using the Mãori Social Survey. Retrieved from www.stats.govt.nz.

Tufts Interdisciplinary Evaluation Research. (2015). A randomized controlled trial of a statewide home visiting programme for young parents. Final report to the Children's Trust of Massachusetts_Executive summary. Medford, MA: Tufts University.

United Nations. (2007). United Nations Declaration on the Rights of Indigenous Peoples. Geneva: United Nations.

Vaithianathan, R., Maloney, T., Jiang, N., De Haan, I., Dale, C., PutnamHornstein, E., . . . Thompson, D. (2012). Vulnerable children: Can administrative data be used to identify children at risk of adverse outcomes? Wellington: Ministry of Social Development.

Vaithianathan, R., Maloney, T., Putnam-Hornstein, E. \& Jiang, N. (2013). Children in the public benefit system at risk of maltreatment: Identification via predictive modelling. American Journal of Preventative Medicine, 45(3), 354-359. 
Vaithianathan, R., Maloney, T., Wilson, M., and Joyce, S. (2017). Family Start impact study: Selected extensions. Wellington: Ministry of Social Development. Retrieved from https://www.msd.govt.nz/about-msd-andour-work/publications-resources/evaluation/family-start-outcomes-study/ index.html

Vaithianathan, R., Wilson, M., Maloney, T., \& Baird, S. (2016). The impact of the Family Start home visiting programme on outcomes for mothers and children: A quasi-experimental study. Wellington: Ministry of Social Development.

Wilson, M. L., Tumen, S., Ota, R., \& Simmers, A. G. (2015). Predictive modelling: Potential application in prevention services. American Journal of Preventative Medicine, 8(5), 509-519.

Wilson, M., \& Cram, F. (in press). Predictive modelling. In C. Davidson, \& M. Tolich (Eds.), Social science research in New Zealand. Auckland: Auckland University Press.

Wüst, M. (2012). Early interventions and infant health: Evidence from the Danish home visiting programme. Labour Economics, 19, 484-495.

\section{The Authors}

Fiona Cram (Katoa Ltd), Min Vette (Oranga Tamariki), Moira Wilson (Ministry of Social Development), Rhema Vaithianathan (Auckland University of Technology (AUT)), Tim Maloney (AUT) and Sarah Baird (George Washington University).

Email: anzea.evaluationmatters@gmail.com 